\title{
Regulation of phytoplankton carbon to chlorophyll ratio by light, nutrients and temperature in the Equatorial Pacific Ocean: a basin-scale model
}

\author{
X. J. Wang ${ }^{1}$, M. Behrenfeld ${ }^{2}$, R. Le Borgne ${ }^{3}$, R. Murtugudde ${ }^{1}$, and E. Boss ${ }^{4}$ \\ ${ }^{1}$ University of Maryland, College Park, Maryland, USA \\ ${ }^{2}$ Oregon State University, Corvallis, Oregon, USA \\ ${ }^{3}$ Institut de Recherche pour le Développement, Nouméa Cédex, New Caledonia, France \\ ${ }^{4}$ School of Marine Sciences, University of Maine, Orono, Maine, USA \\ Received: 15 August 2008 - Published in Biogeosciences Discuss.: 25 September 2008 \\ Revised: 26 February 2009 - Accepted: 5 March 2009 - Published: 17 March 2009
}

\begin{abstract}
The complex effects of light, nutrients and temperature lead to a variable carbon to chlorophyll $(\mathrm{C}: \mathrm{Chl}) \mathrm{ra}-$ tio in phytoplankton cells. Using field data collected in the Equatorial Pacific, we derived a new dynamic model with a non-steady $\mathrm{C}: \mathrm{Chl}$ ratio as a function of irradiance, nitrate, iron, and temperature. The dynamic model is implemented into a basin-scale ocean circulation-biogeochemistry model and tested in the Equatorial Pacific Ocean. The model reproduces well the general features of phytoplankton dynamics in this region. For instance, the simulated deep chlorophyll maximum (DCM) is much deeper in the western warm pool $(\sim 100 \mathrm{~m})$ than in the Eastern Equatorial Pacific $(\sim 50 \mathrm{~m})$. The model also shows the ability to reproduce chlorophyll, including not only the zonal, meridional and vertical variations, but also the interannual variability. This modeling study demonstrates that combination of nitrate and iron regulates the spatial and temporal variations in the phytoplankton C:Chl ratio in the Equatorial Pacific. Sensitivity simulations suggest that nitrate is mainly responsible for the high $\mathrm{C}: \mathrm{Chl}$ ratio in the western warm pool while iron is responsible for the frontal features in the C:Chl ratio between the warm pool and the upwelling region. In addition, iron plays a dominant role in regulating the spatial and temporal variations of the C:Chl ratio in the Central and Eastern Equatorial Pacific. While temperature has a relatively small effect on the $\mathrm{C}: \mathrm{Chl}$ ratio, light is primarily responsible for the vertical decrease of phytoplankton $\mathrm{C}: \mathrm{Chl}$ ratio in the euphotic zone.
\end{abstract}

Correspondence to: X. J. Wang

(wwang@essic.umd.edu)

\section{Introduction}

There are no direct in situ measurements of phytoplankton carbon biomass. Usually, it is estimated from the cell biovolume through microscopic measurement and flow cytometry (e.g., Ishizaka et al., 1997; Chavez et al., 1996; Brown et al., 2003). This approach is time-consuming, thus cannot be employed routinely in field studies. Alternatively, phytoplankton biomass is often inferred from chlorophyll" $a$ " (named Chl, hereafter), a pigment that is common to all planktonic autotrophs and can be easily measured. As a result, there has been extensive and growing database of in situ measurements and remotely sensed Chl. Over the past decade, remotely sensed Chl concentrations have been used for the estimations of the global oceanic primary productivity (Behrenfeld et al., 2005; Behrenfeld and Falkowski, 1997; Carr et al., 2006; Westberry et al., 2008). The extensive Chl database also provides a major reality check on the performance of biogeochemical/ecosystem models (Faure et al., 2006; Armstrong, 2006). However, these approaches rely on realistic conversion between the phytoplankton carbon biomass and $\mathrm{Chl}$ concentration.

The relationship between the phytoplankton carbon biomass and $\mathrm{Chl}$ concentration is non-linear because of the complex influences by light, nutrients and temperature in the euphotic zone (Armstrong, 2006; Behrenfeld et al., 2002, 2005; Geider et al., 1996, 1997, 1998; Brown et al., 2003; Le Bouteiller et al., 2003). It is well known that the phytoplankton carbon to $\mathrm{Chl}(\mathrm{C}: \mathrm{Chl})$ ratio decreases from high light to low light under nutrient-replete conditions, a phenomenon called "photoacclimation". The first dynamic model for

Published by Copernicus Publications on behalf of the European Geosciences Union. 
photoacclimation under nutrient-replete and constant temperature conditions was developed in 1996 (Geider et al., 1996). There have been attempts since to include phytoplanktonic acclimation to nutrients and temperature in the dynamic model development (e.g., Geider et al., 1997, 1998; Behrenfeld et al., 2002; Armstrong, 2006; Pahlow, 2005; Smith and Yamanaka, 2007). Most of these approaches are based on laboratory experiments under controlled conditions. The combined effects of light, nutrients and temperature on the phytoplankton C:Chl ratio in the real ocean are not well known.

Phytoplankton dynamic models have been implemented into simple one dimensional biological models (Taylor et al., 1997; Fennel and Boss, 2003; Lefevre et al., 2003; Faugeras et al., 2004; Fujii et al., 2007) and three dimensional regional to global ocean biogeochemical models (Moore et al., 2002; Aumont et al., 2003; Faure et al., 2006). While some of the modeling studies have attempted to simulate a variable $\mathrm{C}: \mathrm{Chl}$ ratio, there have been limited studies assessing model performance in simulating the phytoplankton C:Chl ratio or Chl (e.g., Fujii et al., 2007; Faure et al., 2006; Lefevre et al., 2003; Doney et al., 2009). Limited studies show considerable mismatches between model outputs and observations, including the seasonal to interannual variations of Chl, phytoplankton carbon biomass, and/or C: Chl ratio (e.g., Lefevre et al., 2003; Doney et al., 2009). Moreover, little is known about the relative roles of light, temperature and nutrients regulating the large scale variability in the phytoplankton C:Chl ratio. These environmental conditions are most likely to change in association with anticipated future climate change and ocean stratification, suggesting implications for the marine ecosystem dynamics and the carbon cycle. Clearly, studies are needed for both improvement/validation of dynamic models and understanding of mechanism underlying the variability of the $\mathrm{C}: \mathrm{Chl}$ ratio. As Armstrong (2006) pointed out: "the ability to predict phytoplankton growth rates under light and nutrient limitations is fundamental to modeling the ocean carbon cycle, equally fundamental is the ability to predict chlorophyll:carbon ratios, since satellite-based chlorophyll estimates are one of the few data sets to which model output can be compared".

Here, we report an approach of using field data to derive and parameterize the phytoplankton $\mathrm{C}$ :Chl ratio as a function of light, temperature, dissolved iron and nitrate, and employing a basin scale 3-dimensional physical-biogeochemical model to test the dynamic model for the Equatorial Pacific. The coupled model has demonstrable capability for simulating spatial and temporal variations in physical fields (Murtugudde et al., 1996), ecosystem dynamics, and biogeochemical fields (Wang et al., 2005, 2006a, 2008). Our approach includes three major parts. First, we use the in situ data collected along $180^{\circ}$ during October-November 1996 to derive a relationship between the phytoplankton $\mathrm{C}: \mathrm{Chl}$ ratio and regulating factors (i.e., light, nutrients and temperature). We then validate the model by using the zonal and meridional distributions of in situ Chl in the upper water column collected from different periods and different locations, and by using the ten years of satellite derived surface Chl. Finally, we carry out a sensitivity study to assess the relative roles of light, nutrients and temperature in regulating the phytoplankton C:Chl ratio for different parts of the Equatorial Pacific Ocean.

\section{Methodology}

\subsection{Model description}

The ocean general circulation model (OGCM) is a reducedgravity, primitive-equation, sigma-coordinate model that is coupled to an advective atmospheric mixed layer model (Gent and Cane, 1989; Murtugudde et al., 1996). The model has 20 vertical layers with variable thicknesses. The uppermost layer, the mixed layer, is determined by surface turbulent kinetic energy generation, dynamic instability mixing, and convective mixing to remove static instabilities (Chen et al., 1994). The mixed layer ranges from 10 to $50 \mathrm{~m}$ along the Equator, and the remaining layers in the euphotic zone $(0-120 \mathrm{~m})$ are approximately $10 \mathrm{~m}$ in thickness. The model is set up for the Pacific domain between $30^{\circ} \mathrm{S}-30^{\circ} \mathrm{N}$ with zonal resolution of $1^{\circ}$, and variable meridional resolutions of $0.3-0.6^{\circ}$ between $15^{\circ} \mathrm{S}-15^{\circ} \mathrm{N}\left(1 / 3^{\circ}\right.$ at latitudes $\left.<10^{\circ}\right)$, increasing to $2^{\circ}$ at the northern and southern boundaries. In the "sponge layer" $\left(10^{\circ}\right.$ band $)$ near the boundaries, temperature, salinity, and nitrate are gradually relaxed back towards climatology from the WOA98 atlas (http://www.nodc.noaa.gov/ OC5/data_woa.html). The model is forced by climatological monthly means of solar radiation and cloudiness, and 6-day means of surface wind stress from the NCEP/NCAR reanalysis (Kalnay et al., 1996). Initial conditions are taken from a climatological run, which has been spun up for 30 years with initial conditions from the WOA98 atlas. We perform an interannual run starting from 1987, and use model outputs from the period of 1994-2007.

The biogeochemical model, modified from an early version (Wang et al., 2006b; Christian et al., 2002), consists of three nutrients (nitrate, ammonium, dissolved iron) and seven biological pools. The biological components include large and small sizes of phytoplankton $\left(\mathrm{P}_{S}\right.$ and $\left.\mathrm{P}_{L}\right)$, zooplankton $\left(Z_{S}\right.$ and $\left.Z_{L}\right)$ and detritus $\left(D_{S}\right.$ and $\left.D_{L}\right)$, respectively, and dissolved organic nitrogen. All biological components are carried in terms of their nitrogen equivalence, except for dissolved iron which is modeled explicitly, using a single $\mathrm{Fe}: \mathrm{N}$ ratio for all biological compartments except the large phytoplankton. Model structure, equations and biological parameters are given in Wang et al. (2008). The incorporation of iron into the ecosystem model is of vital importance in better predicting the ecosystem response, especially in the Equatorial Pacific, because iron has been identified as an important element controlling phytoplankton 
growth in this region (Martin et al., 1994; Coale et al., 1996). We apply a constant Redfield carbon to nitrogen $(\mathrm{C}: \mathrm{N})$ ratio (6.625) to compute the phytoplankton carbon biomass. Then we compute chlorophyll concentration using a diagnostic conversion, i.e., the phytoplankton C:Chl ratio. Our approach of applying a constant $\mathrm{C}: \mathrm{N}$ ratio may have implications for chlorophyll estimation. However, the uncertainties or potential errors would be small because of a relatively small range of $\mathrm{C}: \mathrm{N}$ ratio in phytoplankton uptake (Raimbault et al., 1999).

2.2 Derivation and parameterization of the phytoplankton C:Chl ratio

During the Etude du Broutage en Zone Equatoriale (EBENE) cruise, phytoplankton biomass and chlorophyll concentration were determined from $8^{\circ} \mathrm{S}$ to $8^{\circ} \mathrm{N}$, along $180^{\circ}$ during the period of 21 October to 20 November 1996 (Brown et al., 2003). The EBENE data show that the bulk C:Chl ratio in the community varied greatly near the sea surface (79-155 g:g), but was relatively constant $(\sim 40 \mathrm{~g}: \mathrm{g})$ near the bottom of the euphotic zone. In addition, Le Bouteiller et al. (2003) reports a linear decrease in the phytoplankton $\mathrm{C}$ :Chl ratio with depth in the euphotic zone. As shown in Fig. 1, we can predict the $\mathrm{C}$ :Chl ratio $(\eta)$ as a function of depth $(Z)$ :

$\eta=\eta_{0}-\left(\eta_{0}-\eta_{\mathrm{MIN}}\right) \frac{Z}{Z_{E}}$

where $\eta_{0}$ is the $\mathrm{C}: \mathrm{Chl}$ ratio at the surface, $\eta_{\mathrm{MIN}}$ the minimum C:Chl ratio at the bottom of the euphotic zone $\left(Z_{E}\right)$. At a given depth $Z(Z>0)$, light condition can be predicted as:

$I(z)=I_{0} \exp ^{-k_{A} Z}$,

where $I_{0}$ is the photosynthetically available radiation (PAR) at the surface. The term $k_{A}$, a light attenuation coefficient, is computed as:

$k_{A}=k_{W}+k_{C} \mathrm{Chl}+k_{D}\left(D_{S}+D_{L}\right)$

where $k_{W}, k_{C}, k_{D}$ are the attenuation coefficients for water, chlorophyll and detritus, respectively. There is evidence of uniform distribution in particulate organic nitrogen in the euphotic zone of the Equatorial Pacific (Wang et al., 2008), suggesting probably uniform distribution of detritus. Observation also shows relatively uniform distribution of chlorophyll concentration in the upper $100 \mathrm{~m}$ at $0^{\circ}$ and $3^{\circ} \mathrm{S}$ along $180^{\circ}$ during the EBENE cruise (see Fig. 6 in Le Bouteiller et al., 2003). Hence, we assume that $k_{A}$ is constant in the euphotic zone.

By replacing the variable $Z$ by the variable $I$, we can rewrite Eq. (1) as:

$\eta=\eta_{0}-\left(\eta_{0}-\eta_{\mathrm{MIN}}\right) \frac{\ln I_{0}-\ln I}{\ln I_{0}-\ln I_{Z_{E}}}$, where $I_{Z_{E}}$, the PAR value at the euphotic depth, is $1 \%$ of the surface PAR (i.e., $I_{Z_{E}}=0.01 I_{0}$ ). Thus, we can simplify Eq. (4) as:

$\eta=\eta_{0}-\left(\eta_{0}-\eta_{\mathrm{MIN}}\right) \frac{\ln I_{0}-\ln I}{4.605}$.

While an early study reported an empirical relationship between phytoplankton Chl:C ratio and growth rate (Cloern et al., 1995), Le Bouteiller et al. (2003) shows that the surface $\mathrm{C}: \mathrm{Chl}$ ratio linearly decreases with increasing the growth rate $\left(\mu_{0}^{*}\right)$ under non-light limitation conditions:

$\eta_{0}=\eta_{\mathrm{MAX}}-k_{P} \mu_{0}^{*}$,

where $\eta_{\mathrm{MAX}}$ is the maximum $\mathrm{C}: \mathrm{Chl}$ ratio, and $k_{P}$ the slope of $\mathrm{C}$ :Chl ratio vs. growth rate. There has been other observational evidence that the phytoplankton $\mathrm{C}$ : Chl ratio decreases with increased growth rate under non-light limitation conditions (Geider et al., 1997, 1998; Armstrong, 2006; Behrenfeld et al., 2005). The non-light limited growth rate, $\mu_{0}^{*}$, can be computed as a function of temperature $(T)$ and the minimum (min) nutrient availability of nitrate $(\mathrm{N})$ and iron $(\mathrm{Fe})$ :

$\mu_{0}^{*}=\mu_{0} e^{k_{T} T} \min \left(\frac{\mathrm{NO}_{3}}{K_{N}+\mathrm{NO}_{3}}, \frac{\mathrm{Fe}}{K_{\mathrm{Fe}}+\mathrm{Fe}}\right)$,

where $\mu_{0}$ is the maximum growth rate at $0^{\circ} \mathrm{C}$, and $k_{T}$ the temperature dependence coefficient for phytoplankton growth. $K_{N}$ and $K_{\mathrm{Fe}}$ are the half saturation constants for nitrogen and iron limitations on phytoplankton growth, respectively.

There are two phytoplankton categories (large and small) in the model. The small phytoplankton, primarily picophytoplankton (i.e. $<2 \mu \mathrm{m}$ ), accounts for $>70 \%$ of the phytoplankton community determined by total $\mathrm{Chl}$ under normal conditions, with larger percentages in the oligotrophic western warm pool than in the mesotrophic High-NutrientLow-Chlorophyll (HNLC) region of the Equatorial Pacific (Blanchot et al., 2001; Mackey et al., 2002; Le Bouteiller et al., 2003; Le Borgne et al., 2002b). The C:Chl ratio is higher in small phytoplankton cells than in the large ones (Le Bouteiller et al., 2003). Accordingly, we use different physiological parameters for each phytoplankton category (Table 1).

\subsection{Satellite and in situ data}

Table 2 presents details on the in situ and satellite data sets used for model evaluation in this study. The data sets include zonal and meridional distributions of in situ $\mathrm{Chl}$ in the upper $120 \mathrm{~m}$ water column collected from different periods. Particularly, we use in situ $\mathrm{Chl}$ from the FLUPAC and Zonal Flux studies (Le Borgne et al., 2002a) because of the similar spatial coverage (i.e., $165^{\circ} \mathrm{E}-155^{\circ} \mathrm{W}$ ) but for two 
Table 1. Biological parameters used for small and large phytoplankton.

\begin{tabular}{lllll}
\hline Parameter & Symbol & Unit & Small & Large \\
\hline Maximum growth rate at $0^{\circ} \mathrm{C}$ & $\mu_{\mathrm{S} 0}$ & $d^{-1}$ & 0.58 & 1.16 \\
Temp. dependent coefficient for $\mu$ & $k_{T}$ & ${ }^{\circ} \mathrm{C}^{-1}$ & 0.06 & 0.06 \\
Half saturation constant for N limitation & $K_{N}$ & $\mathrm{nmol} \mathrm{m}^{-3}$ & 0.2 & 0.6 \\
Half saturation constant for iron limitation & $K_{F e}$ & $\mathrm{nmol} \mathrm{m}$ & \\
Minimum C:Chl ratio & $\eta_{\mathrm{MIN}}$ & $\mathrm{g}: \mathrm{g}$ & 30 & 150 \\
Maximum C:Chl ratio & $\eta_{\mathrm{MAX}}$ & $\mathrm{g}: \mathrm{g}$ & 200 & 15 \\
Photoacclimation coefficient & $k_{P}$ & $(\mathrm{~g}: \mathrm{g}) \mathrm{d}$ & 95 & 70 \\
Light attenuation constant for water & $k_{W}$ & $\mathrm{~m}^{-1}$ & & 0.028 \\
Light attenuation constant for chlorophyll & $k_{C}$ & $\mathrm{~m}^{-1}\left(\mathrm{mg} \mathrm{chl} \mathrm{m}^{-3}\right)^{-1}$ & 0.058 \\
Light attenuation constant for detritus & $k_{D}$ & $\mathrm{~m}^{-1}\left(\mathrm{mmol} \mathrm{N} \mathrm{m}^{-3}\right)^{-1}$ & 0.008 \\
\hline
\end{tabular}

Table 2. Description of the evaluation data sets used for model skill assessments.

\begin{tabular}{llllll}
\hline Data sets & Variable & Long. & Lat. & Period & Reference \\
\hline FLUPAC & Chl & $166^{\circ} \mathrm{E}-150^{\circ} \mathrm{W}$ & $0^{\circ}$ & Oct 1994 & Le Borgne et al. (2002a) \\
Zonal Flux & Chl & $165^{\circ} \mathrm{E}-150^{\circ} \mathrm{W}$ & $0^{\circ}$ & May 1996 & Le Borgne et al. (2002a) \\
EBENE & $\mathrm{C}: \mathrm{Chl}$ & $180^{\circ}$ & $8^{\circ} \mathrm{N}-8^{\circ} \mathrm{S}$ & Oct 1996 & Brown et al. (2003) \\
Box Project & $\mathrm{Chl}$ & $140^{\circ} \mathrm{W}, 125^{\circ} \mathrm{W}$ & $8^{\circ} \mathrm{N}-8^{\circ} \mathrm{S}$ & Sep 2005 & This study \\
& $\mathrm{Chl}$ & $140^{\circ} \mathrm{W}, 125^{\circ} \mathrm{W}$ & $8^{\circ} \mathrm{N}-8^{\circ} \mathrm{S}$ & Aug 2006 & This study \\
& $\mathrm{Chl}$ & $140^{\circ} \mathrm{W}, 125^{\circ} \mathrm{W}$ & $8^{\circ} \mathrm{N}-8^{\circ} \mathrm{S}$ & May 2007 & This study \\
SeaWiFS & $\mathrm{Chl}$ & $150^{\circ} \mathrm{E}-90^{\circ} \mathrm{W}$ & $15^{\circ} \mathrm{N}-15^{\circ} \mathrm{S}$ & $1998-2007$ & McClain et al. (2002) \\
\hline
\end{tabular}

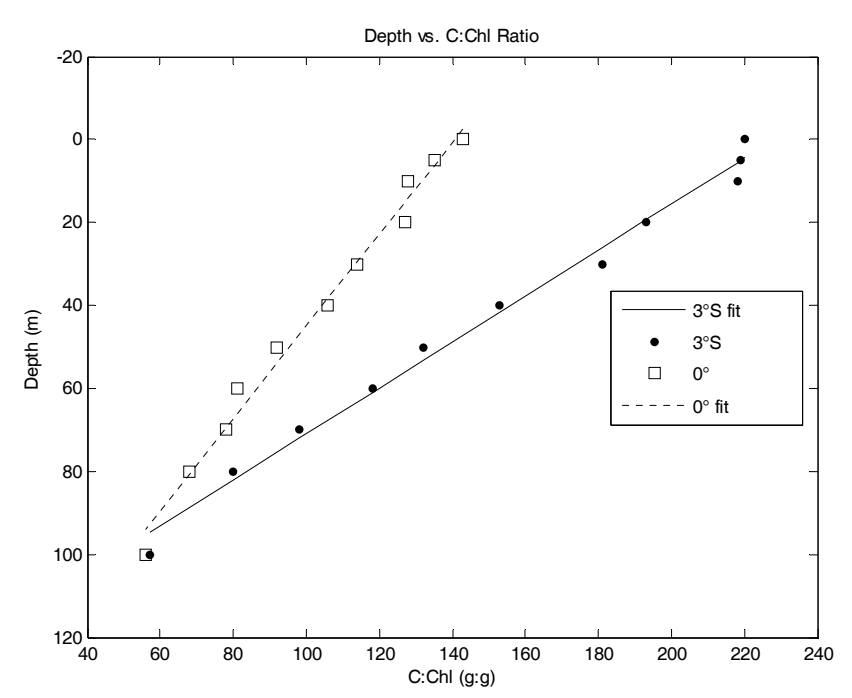

Fig. 1. Measured vertical distribution of community C:Chl ratio at $0^{\circ}$ and $3^{\circ} \mathrm{S}$ along $180^{\circ}$ during October-November 1996. Data are from the Table 6 in Le Bouteiller et al. (2003).

different phases of the El Niño/Southern Oscillation (ENSO) cycle. September-October 1994 corresponds to the warm phase while April-May 1996 is in the cold phase of the ENSO cycle.
As part of the Equatorial Box Project (http://web.science. oregonstate.edu/ocean.productivity/box.php), water samples were collected during the Tropical Atmosphere Ocean (TAO) cruises along $140^{\circ} \mathrm{W}$ and $125^{\circ} \mathrm{W}$ during 2005-2007. Surface particulate organic carbon (POC) concentrations were measured by collecting water samples at $3 \mathrm{~m}$ using the flowthrough seawater system. Chl concentrations were determined using a Turner fluorometer and by HPLC. Technical details can be found in Behrenfeld and Boss (2006). The in situ $\mathrm{Chl}$ and POC data can be accessed at the project website. We use these data for further model validations, focusing on meridional variations in the Eastern Equatorial Pacific.

There is a continuous record of high-quality ocean color data from the Sea-viewing Wide Field-of-view Sensor (SeaWiFS) going back to September 1997. The satellite derived Chl provides spatial distributions and temporal variations, which are useful for validation of the modeled surface $\mathrm{Chl}$ at large scales.

\subsection{Skill metrics for model-data comparisons and model sensitivity studies}

We apply a standard suite of skill metrics, including bias, correlation coefficient, and normalized standard deviation (NSD). The metrics for model skills are applied to different spatial and temporal domains, according to the availability of observations. For the zonal-vertical and meridional-vertical 
distributions, both the observations and model outputs are interpolated and/or extrapolated to fixed depths of 10, 20, 30, 5075,100 and $125 \mathrm{~m}$. For the surface Chl, the SeaWiFS data and model outputs are interpolated into $1^{\circ} \times 1^{\circ}$ and monthly averages for the period of 1998-2007. A perfect model without error would give a value of 1 for both correlation coefficient and the normalized standard deviation. We use Taylor diagram (Taylor, 2001) to display assessments of model skills and model sensitivity studies.

\section{Model results}

\subsection{Along $180^{\circ}$}

The EBENE cruise was executed at the end of the 1995-1996 cold phase of the ENSO cycle (see introduction by Le Borgne and Landry, 2003). The upwelling zone extended west of the dateline, resulting in relatively high nutrient concentrations in the euphotic zone along $180^{\circ}$ (Eldin and Rodier, 2003). Observed Chl concentration reached $0.2 \mathrm{mg} \mathrm{m}^{-3}$ near the surface between $5^{\circ} \mathrm{S}$ and $5^{\circ} \mathrm{N}$, and $\sim 0.3 \mathrm{mg} \mathrm{m}^{-3}$ at the DCM depth (Brown et al., 2003). Figure 2 shows that modeled surface $\mathrm{Chl}$ concentration is greater than $0.2 \mathrm{mg} \mathrm{m}^{-3}$ east of the dateline on the Equator, reflecting biological response to strong upwelling during the cold phase of the ENSO. Modeled DCM depth is much shallower on the Equator $(30-80 \mathrm{~m})$ than off the Equator $(\sim 100 \mathrm{~m})$, which is similar to the observations. The model reproduces highest phytoplankton biomass near the surface with a sharp decline over depth. Modeled $\mathrm{C}: \mathrm{Chl}$ ratio shows a similar range near the surface (80-140 g:g), and a similar value near the bottom of the euphotic zone ( $\sim 40 \mathrm{~g}: \mathrm{g}$ ) to the observations (Fig. $2 \mathrm{f}$ ).

There are some differences in the meridional distribution of the $\mathrm{C}$ : $\mathrm{Chl}$ ratio between the model and observation, mainly near the surface. The model predicts the lowest $\mathrm{C}$ : Chl ratio near the Equator (i.e., $1^{\circ} \mathrm{N}-3^{\circ} \mathrm{S}$ ) whereas the observations show relatively higher $\mathrm{C}: \mathrm{Chl}$ ratio. This disagreement may partly reflect the difference in ecosystem structure between the simple model and the complicated real ocean as community structure plays a large role in regulating the bulk $\mathrm{C}: \mathrm{Chl}$ variability (Wang et al., 2009). The observed community $\mathrm{C}:$ Chl ratio is similar $(\sim 100 \mathrm{~g}: \mathrm{g})$ at $0^{\circ}$ and $3^{\circ} \mathrm{S}$ whereas the observed $\mathrm{C}$ : $\mathrm{Chl}$ ratio in small cells $(<3 \mu \mathrm{m})$ is lower at $0^{\circ}$ (<150 g:g) than at $3^{\circ} \mathrm{S}(>200 \mathrm{~g}: \mathrm{g})$ (Fig. 1). These suggest that there is a considerable proportion of large cells near the Equator, which has low $\mathrm{C}: \mathrm{Chl}$ ratios, and the model probably underestimates the large phytoplankton biomass in this region.

While a sophisticated ecosystem model would be able to simulate small scale feature, other factors need to be considered for model-data comparisons. Field data may have fine spatial and temporal resolutions that are probably not resolved by the model. In particular, field measurements often represent some events occurring at much shorter time scales which can range from less than one hour to several days whereas our model is limited by the shortest frequency of six days (i.e., wind forcing), and model simulations mostly represent mean conditions at much longer time scales (e.g., weeks to months). For example, the EBENE 5-day time series (4-9 November 1996) reveal significant daily variability in the Chl field. The DCM depth varies from $40 \mathrm{~m}$ to $80 \mathrm{~m}$ and the Chl concentration ranges from $0.29 \mathrm{mg} \mathrm{m}^{-3}$ to $0.38 \mathrm{mg} \mathrm{m}^{-3}$ at the DCM (see Fig. 3a in Neveux et al., 2003). As reported by Eldin and Rodier (2003), most of the observed anomalies reflected La Niña conditions, except for north of the Equator, which was more affected by higherfrequency variability, i.e., the tropical instability wave. In addition, the EBENE cruise captured many frontal features that might not be coherent with the model.

\subsection{Along $140^{\circ} \mathrm{W}$ and $125^{\circ} \mathrm{W}$}

Figure 3 shows model-data comparisons along $140^{\circ} \mathrm{W}$ and $125^{\circ} \mathrm{W}$ for the period of September 2005. The modeled Chl shows a similar range to the in situ $\mathrm{Chl}$ in the upper euphotic zone along $140^{\circ} \mathrm{W}$. The in situ Chl concentrations $\left(0.2-0.5 \mathrm{mg} \mathrm{m}^{-3}\right)$ are slightly higher than the modeled $\mathrm{Chl}$ $\left(0.1-0.4 \mathrm{mg} \mathrm{m}^{-3}\right)$ in the upper euphotic zone along $125^{\circ} \mathrm{W}$. There is a considerable difference in the surface Chl concentrations among the in situ, modeled and the SeaWiFS data. The SeaWiFS Chl concentrations are generally lower with a weaker meridional variation than the in situ surface Chl. The modeled surface Chl shows better agreements with the in situ surface Chl than with the SeaWiFS Chl. This is an indication that further algorithm development is needed to improve the estimation of $\mathrm{Chl}$ from the remotely-sensed ocean color.

Figure 4 presents the comparisons between in situ surface POC and modeled POC in the mixed layer. Modeled POC is converted from particulate organic nitrogen (see details in Wang et al., 2008), using a fixed carbon to nitrogen ratio of 6.625. The uncertainties associated with this approach would be small because the $\mathrm{C}: \mathrm{N}$ ratio in suspended material is relatively constant (Raimbault et al., 1999). Overall, the model reproduces the meridional distribution of surface POC, reasonably well, showing moderate increase (by less than a factor of two) from off the Equator to the Equator. Both the in situ data and model simulation reveal relatively higher surface POC concentrations to the north than to the south during May 2007.

\subsection{Modeled surface Chl vs. the SeaWiFS derived Chl}

There are two distinct regions in the Equatorial Pacific: the upwelling region in the Central and Eastern Pacific and the warm pool to the west (Picaut et al., 2001; Le Borgne et al., 2002a). These two regions are clearly separated by a front, whose longitudinal location is highly correlated to the Southern Oscillation Index (SOI): 173.2-10.75 SOI (Le Borgne et al., 2002a). The SOI values are the standardized 
(a) Chlorophyll (mg m $\left.\mathrm{m}^{-3}\right)$

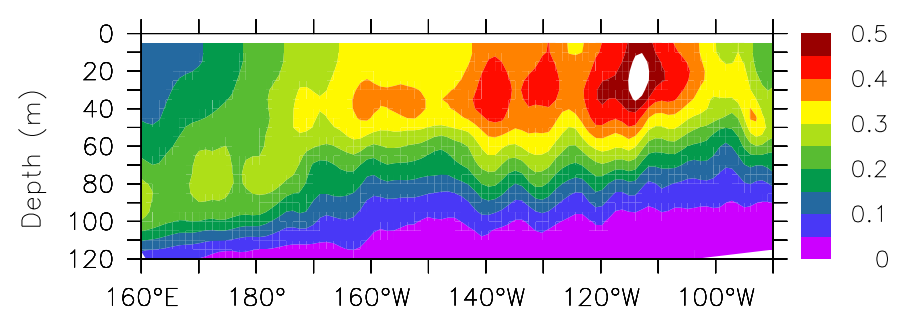

(c) Phytoplankton ( $\mathrm{mg} \mathrm{C} \mathrm{m}^{-3}$ )

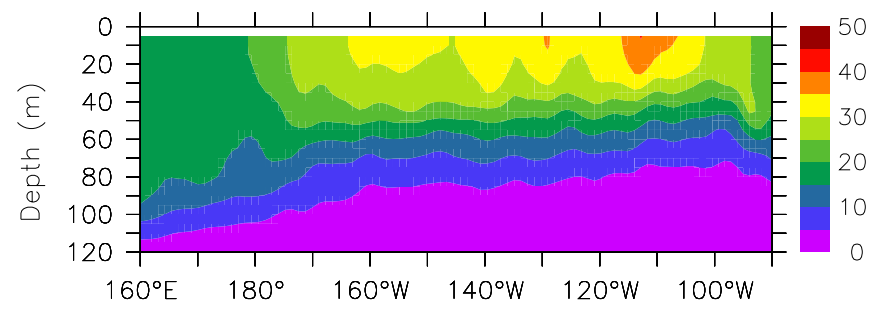

(e) C:Chlorophyll

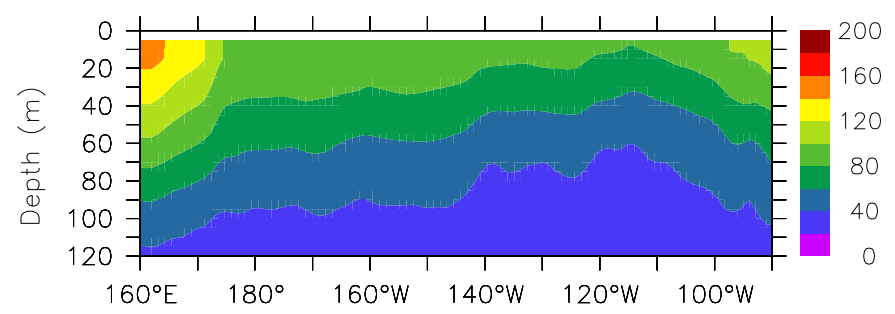

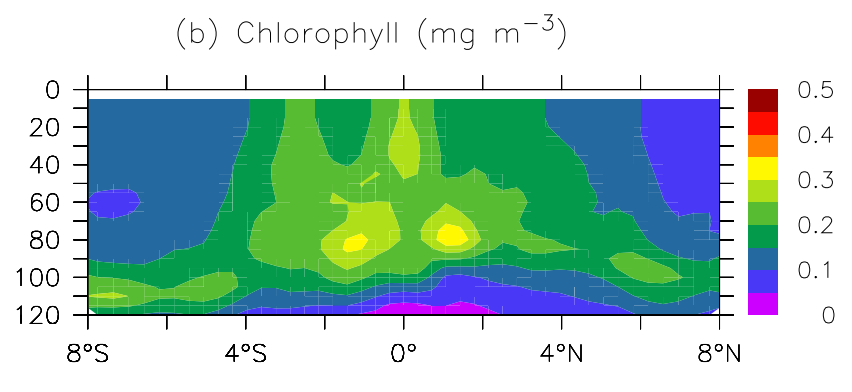

(d) Phytoplankton ( $\mathrm{mg} \mathrm{C}^{-3}$ )

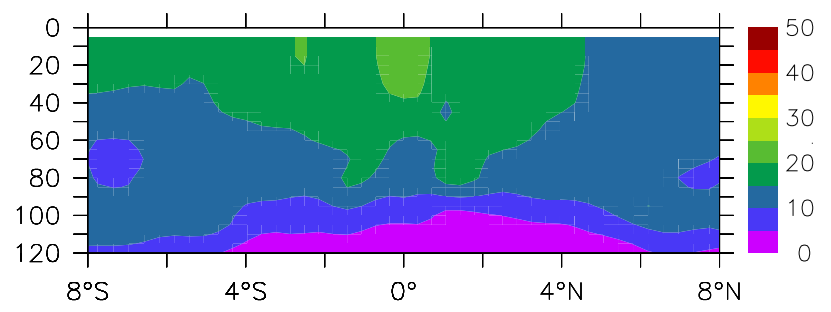

(f) C:Chlorophyll

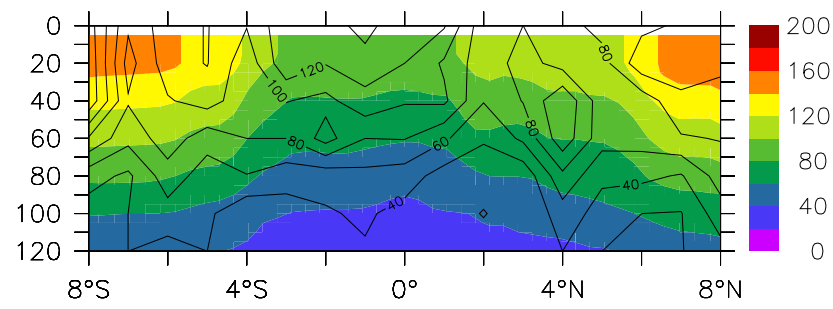

Fig. 2. Modeled zonal (left panel, $1^{\circ} \mathrm{N}-1^{\circ} \mathrm{S}$ ) and meridional (along $180^{\circ}$ ) distributions of (a) and (b) chlorophyll, (c) and (d) phytoplankton biomass, and (e) and (f) C:Chlorophyll ratio during October-November 1996. Contours in (f) are in situ measurements from Brown et al. (2003).

data of Tahiti minus Darwin sea-level pressures from the Climate Prediction Centre (http://www.cpc.ncep.noaa.gov/data/ indices/soi). A negative SOI indicates a warm phase of the ENSO, which is associated with an eastward shift of the front. This front can also be called the HNLC front because the upwelling region often has HNLC conditions (Wang et al., 2006b).

In this section, we compare modeled $\mathrm{Chl}$ with the SeaWiFS data for the period of 1997-2007, emphasizing large scale features, i.e., spatial and temporal variability. Figure 5 displays comparisons in the climatology and standard deviation (s.d.) of surface Chl. The model reproduces the observed surface Chl fields, including the spatial pattern and magnitude. Simulated Chl concentrations in the surface water range from $<0.1 \mathrm{mg} \mathrm{m}^{-3}$ in the western warm pool to $>0.2 \mathrm{mg} \mathrm{m}^{-3}$ in the eastern upwelling region, which is consistent with the SeaWiFS derived Chl. The standard deviation from the model reveals similar spatial variability and magnitude as the SeaWiFS, showing the highest values $\left(\sim 0.1 \mathrm{mg} \mathrm{m}^{-3}\right)$ on the Equator in the eastern upwelling region.
Figure 6 shows that the model simulation captures many observed features in the SeaWiFS Chl over the period of 1997-2007, particularly the seasonal to interannual variability for the HNLC front. The model reproduces the extremely low Chl in the central Equatorial Pacific during the warm phases of 1997/8, 2002 and 2006 ENSO events. While there are large ENSO impacts on surface Chl in the Western and Central Equatorial Pacific, the ENSO impact on the surface $\mathrm{Chl}$ is relatively small in the eastern equatorial $\mathrm{Pa}$ cific region (Fig. 6c). For instance, both model and SeaWiFS Chl show weak interannual variations except for the 1997/8 ENSO event. The averaged in situ Chl concentration is slightly lower during September $2006\left(\sim 0.15 \mathrm{mg} \mathrm{m}^{-3}\right)$ than during September $2005\left(\sim 0.25 \mathrm{mg} \mathrm{m}^{-3}\right)$ and May 2007 $\left(\sim 0.18 \mathrm{mg} \mathrm{m}^{-3}\right)$.

The model underestimates $\mathrm{Chl}$ concentration during the cold phase of 1998 ENSO, which could be related to the overall weak amplitude of the NCEP winds (Hackert et al., 2001). There is also a mis-match in the Eastern Equatorial Pacific between the model and the SeaWiFS Chl. On the one hand, the SeaWiFS dataset underestimates the surface Chl concentration for the upwelling region (Fig. 6c). On the other hand, 

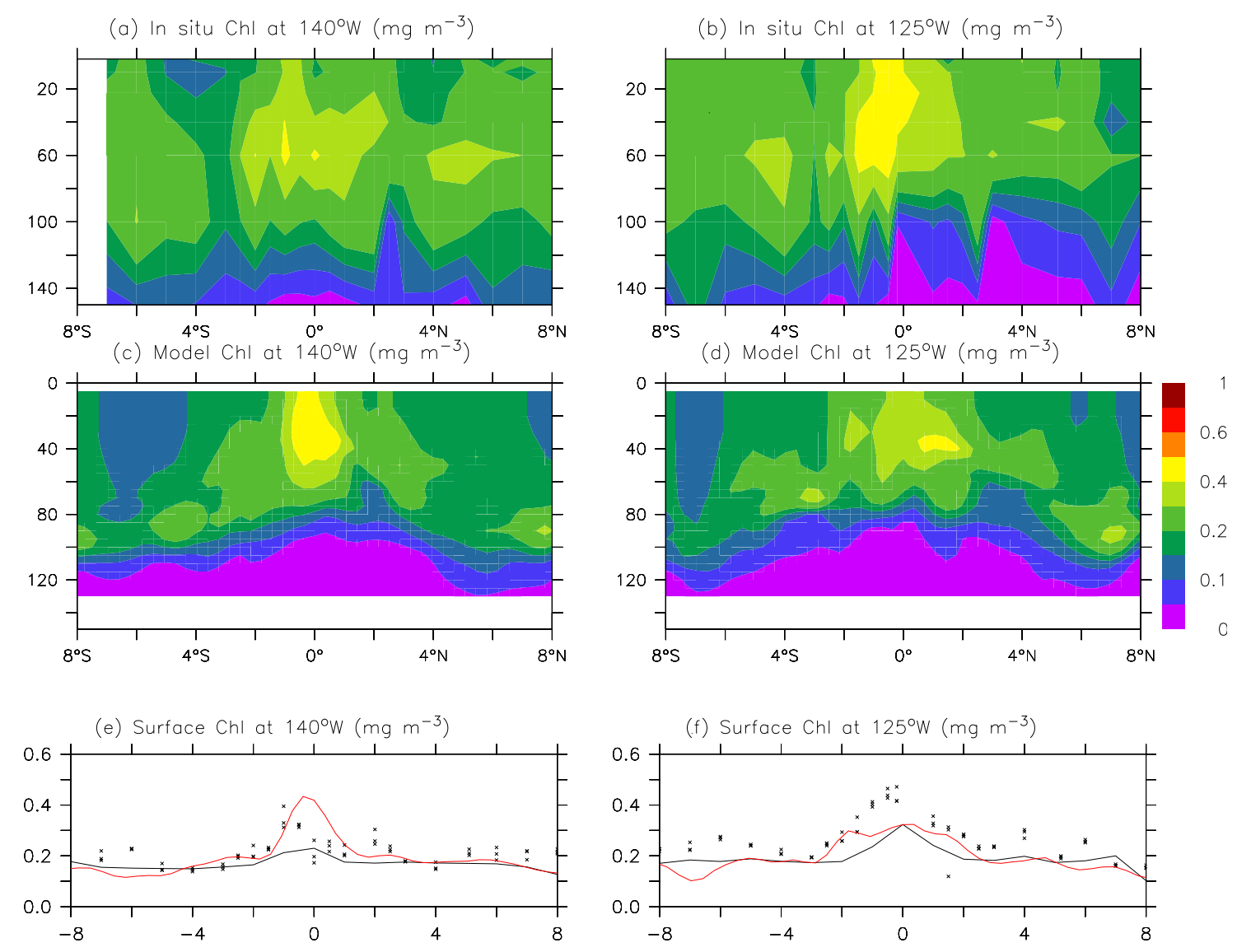

Fig. 3. SeaWiFS, in situ and modeled chlorophyll during September 2005. In situ chlorophyll (a) along $140^{\circ} \mathrm{W}$ and (b) along $125^{\circ} \mathrm{W}$, and modeled chlorophyll (c) along $140^{\circ} \mathrm{W}$ and (d) along $125^{\circ} \mathrm{W}$, and surface (0-20 m) chlorophyll concentrations (e) along $140^{\circ} \mathrm{W}$ and (f) along $125^{\circ} \mathrm{W}$ from in situ (symbols), model (red lines) and SeaWiFS (black lines).

the model may not be able to reproduce the spatial and temporal variability at small scales due to model deficiency in physical field (e.g., seasonality in the Eastern Equatorial Pacific, Wang et al., 2006a), in association with the standard cold-bias in most state of the art ocean models (see Murtugudde et al., 2002).

\subsection{Overall model skill assessment}

The Equatorial Pacific Ocean is characterized for its large spatial and temporal variations in physical and biogeochemical properties, which must be considered for model validations. In this study, we use several data sets to provide overall assessments for the dynamic phytoplankton model. The data sets include zonal and meridional distributions of water column in situ Chl concentration, spinning from 1994 to 2007. The in situ and satellite $\mathrm{Chl}$ data sets are compared with the model $\mathrm{Chl}$ from the hindcast simulation. Figure 7 illustrates that the correlation coefficient $(r)$ ranges from 0.3 to 0.7 , and NSD from $\sim 1$ to 1.5 . Although the model simulation does not capture some features in the $\mathrm{C}: \mathrm{Chl}$ ratio
(Fig. 2f), the model-data comparison of $\mathrm{C}: \mathrm{Chl}$ ratio yields a correlation coefficient of 0.41 and a NSD of 1.2. Overall, the model shows better skills in simulating zonal Chl distribution $(r>0.7)$ than in simulating meridional Chl distribution $(r=0.3-0.65)$. The model hindcast simulation exhibits promising skills in producing large scale spatial and temporal variability of surface $\mathrm{Chl}$, with the correlation coefficient greater than 0.7 and the NSD close to 1 .

\section{Discussion}

\subsection{Variable $\mathrm{C}: \mathrm{Chl}$ ratio vs. constant $\mathrm{C}: \mathrm{Chl}$ ratio}

We have formulated a variable phytoplankton C:Chl ratio to estimate the spatial and temporal distributions of $\mathrm{Chl}$ in the Equatorial Pacific Ocean. While the basin scale model is able to predict $\mathrm{Chl}$ concentrations, it would be clearly instructive to conduct a comparison, i.e., variable $\mathrm{C}$ : $\mathrm{Chl}$ ratio vs. constant C:Chl ratio. Many regional and global biogeochemical models often use a constant $\mathrm{C}$ :Chl ratio to com- 

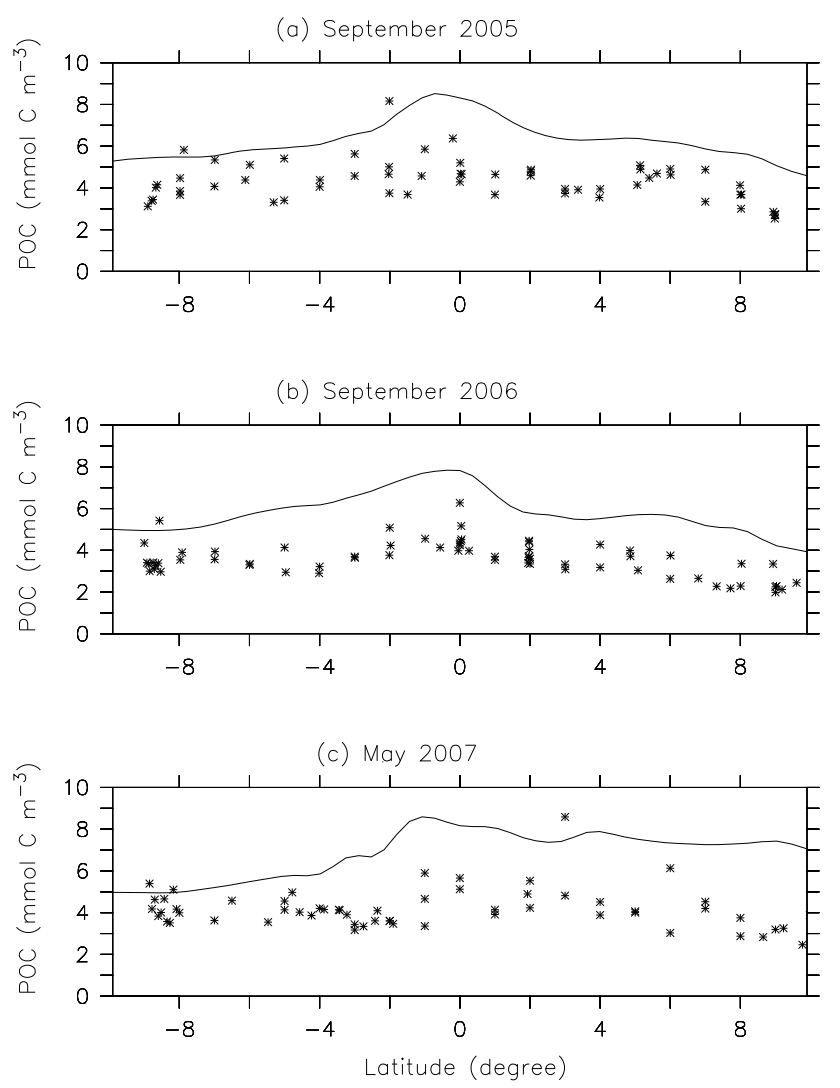

Fig. 4. Modeled (lines) versus measured (symbols) surface concentrations of POC $\left(140^{\circ} \mathrm{W}-125^{\circ} \mathrm{W}\right)$ during (a) September 2005 , (b) September 2006, and (c) May 2007.

pute Chl from simulated phytoplankton biomass (e.g., Wetzel et al., 2006). Here, we compare Chl fields from the standard simulation (i.e., with a variable C:Chl ratio) with those generated from phytoplankton biomass with (1) a constant $\mathrm{C}: \mathrm{Chl}$ ratio of $80 \mathrm{~g}: \mathrm{g}$ and (2) a vertically decreasing C:Chl ratio from $100 \mathrm{~g}: \mathrm{g}$ at the surface to $50 \mathrm{~g}: \mathrm{g}$ at $100 \mathrm{~m}$. Figure 8 demonstrates that there are considerable differences in the distribution of $\mathrm{Chl}$ fields. The standard simulation shows a deeper DCM $(\sim 100 \mathrm{~m})$ in the western warm pool and a shallower one $(\sim 50 \mathrm{~m})$ in the upwelling region. Modeled surface Chl concentration is less than $0.1 \mathrm{mg} \mathrm{m}^{-3}$ in the warm pool and $>0.25 \mathrm{mg} \mathrm{m}^{-3}$ in the HNLC area. Chl concentration at the DCM displays a small range $\left(0.2-0.3 \mathrm{mg} \mathrm{m}^{-3}\right)$ in both the western warm pool and the upwelling region. These features in the modeled Chl fields are consistent with the observations in the Equatorial Pacific Ocean (Le Borgne et al., 2002a). With a constant $\mathrm{C}: \mathrm{Chl}$ ratio, the generated $\mathrm{Chl}$ field shows no DCM in the upwelling region and a weak DCM in the warm pool, and an overestimate of surface Chl concentrations, particularly to the west. Applying a decreasing $\mathrm{C}: \mathrm{Chl}$ ratio over depth seems be able to generate a DCM, indicating the role of photoacclimation on DCM formation. However, this approach underestimates the spatial variability, particularly the west-east contrast.
Table 3. Model experiments with different combinations of variables in Eq. (7).

\begin{tabular}{lccc}
\hline Experiment & $\begin{array}{c}\text { SST } \\
\left({ }^{\circ} \mathrm{C}\right)\end{array}$ & $\begin{array}{c}\text { Nitrate } \\
\left(\mathrm{mmol} \mathrm{m}^{-3}\right)\end{array}$ & $\begin{array}{c}\text { Iron } \\
\left(\mathrm{nmol} \mathrm{m}^{-3}\right)\end{array}$ \\
\hline Standard & Variable & Variable & Variable \\
SSTM & 26.9 & Variable & Variable \\
$\mathrm{FeM}$ & Variable & Variable & 18.9 \\
$\mathrm{NO}_{3} \mathrm{M}$ & Variable & 4 & Variable \\
$\mathrm{FeNO}_{3} \mathrm{M}$ & Variable & 4 & 18.9 \\
\hline
\end{tabular}

\subsection{Relative role of nutrients and temperature}

We have developed a dynamic phytoplankton model that predicts a variable $\mathrm{C}: \mathrm{Chl}$ ratio as a function of temperature, nitrate, iron and light. Our model simulates large spatial and temporal variations in the phytoplankton $\mathrm{C}: \mathrm{Chl}$ ratio for the Equatorial Pacific (Wang et al., 2009). However, little is known about the relative role of nutrients and temperature on the phytoplankton $\mathrm{C}: \mathrm{Chl}$ ratio. To address this issue, we carry out a sensitivity study consisting of a standard simulation and four sensitivity experiments (Table 3). For the standard simulation, we keep SST, iron and nitrate concentrations variable in Eq. (7). For the sensitivity simulations, we apply one or two constants that are the averaged values of SST, surface iron or/and nitrate concentrations calculated from the standard simulation for the year 1994. We then compare simulated C:Chl ratio with that from the standard simulation for the period of September-October 1994. We choose this period because it has in situ $\mathrm{Chl}$ data for model validation, and the year 1994 is close to an average year with a slightly negative SOI.

SST is high year around in the Equatorial Pacific, varying from $22^{\circ} \mathrm{C}$ in the eastern upwelling region to $\sim 30^{\circ} \mathrm{C}$ in the warm pool. Replacing the variable SST in Eq. (7) with a constant value results in little change in model simulations of the zonal and meridional variations of the phytoplankton C:Chl ratio (Figs. 9a, 10a and b), indicating that temperature has little effect on the $\mathrm{C}$ :Chl ratio in the Equatorial Pacific. Applying a constant iron concentration causes moderate changes in the phytoplankton C:Chl ratio (Figs. 9b, $10 \mathrm{c}$ and $\mathrm{d}$ ). The model considerably underestimates the $\mathrm{C}$ : Chl ratio near the front (i.e., $180^{\circ}-160^{\circ} \mathrm{W}$ ) between the warm pool and the HNLC waters. Eliminating nitrate effect results in large changes in the magnitude and meridional variability of the phytoplankton C:Chl ratio in the warm pool (Figs. 9c and 10e). However, nitrate shows little effect on the phytoplankton dynamics in the area east of $160^{\circ} \mathrm{W}$ (Figs. 9c and 10f). These results suggest that nitrate is the primary factor regulating the phytoplankton $\mathrm{C}: \mathrm{Chl}$ ratio in the western warm pool whereas iron plays an important role near the HNLC frontal region. These two limitations, nitrate in the oligotrophic warm pool and iron in the mesotrophic re- 
(a) Modeled chlorophyll ( $\mathrm{mg} \mathrm{m}^{-3}$ )

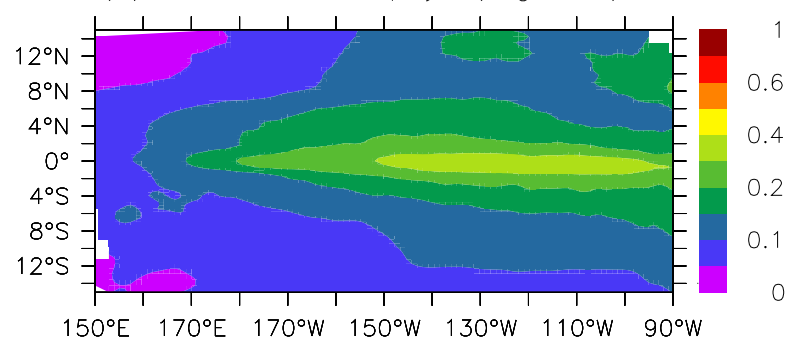

(c) SeaWiFS chlorophyll $\left(\mathrm{mg} \mathrm{m}^{-3}\right)$

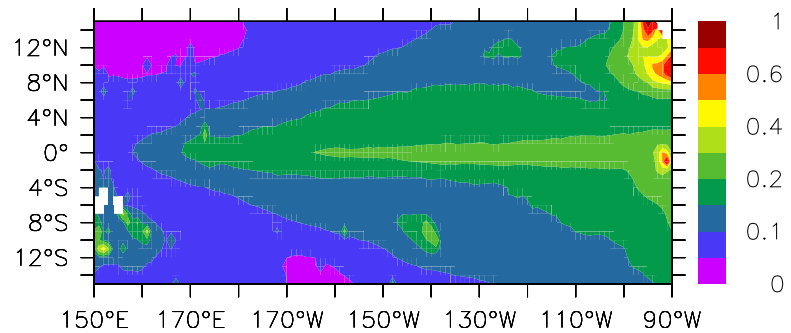

(b) Model chl. s.d. ( $m g \mathrm{~m}^{-3}$ )

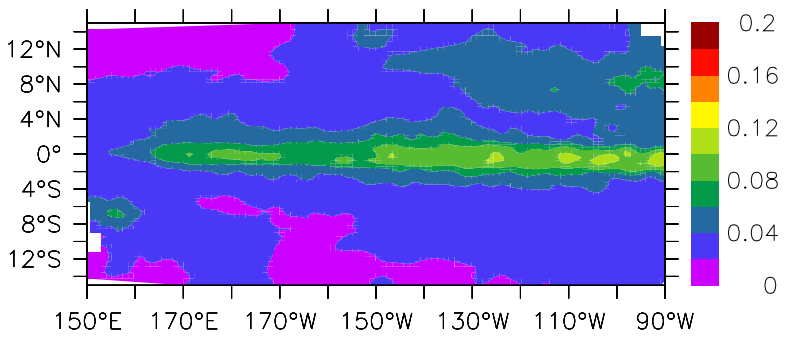

(d) SeaWiFs chl. s.d. $\left(\mathrm{mg} \mathrm{m}^{-3}\right)$

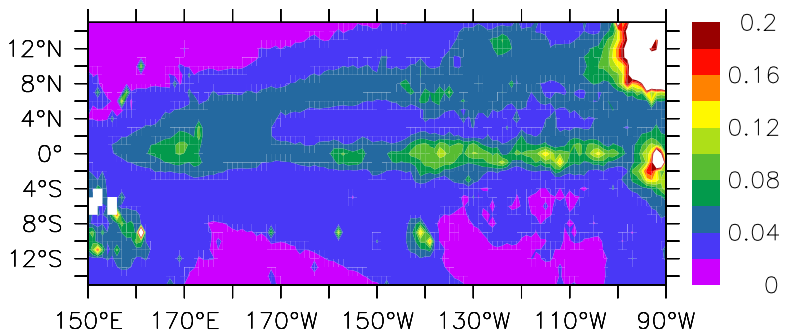

Fig. 5. Climatology (1997-2007) of surface chlorophyll from (a) model and (c) SeaWiFS, and (b) and (d) the standard deviations (s.d.) computed for monthly data.

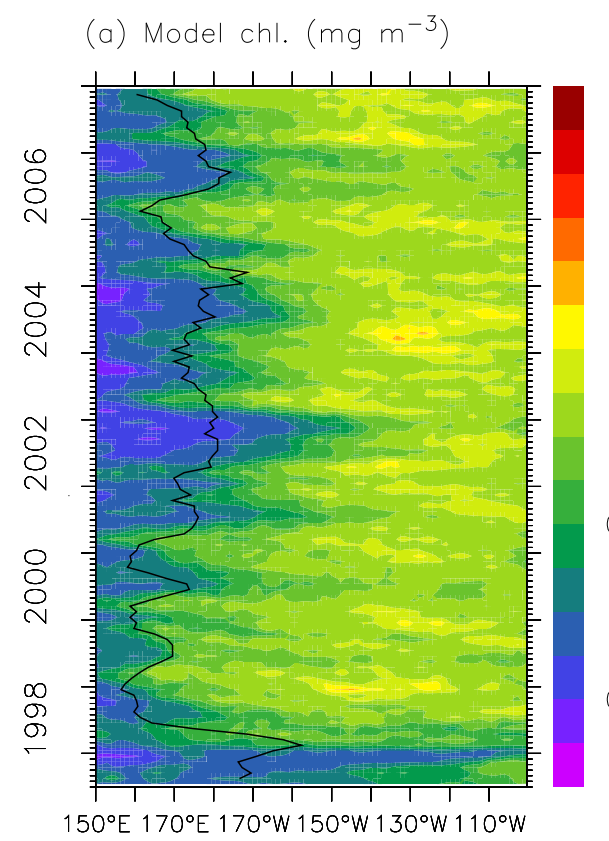

(b) SeaWiFs chl. $\left(\mathrm{mg} \mathrm{m}^{-3}\right)$

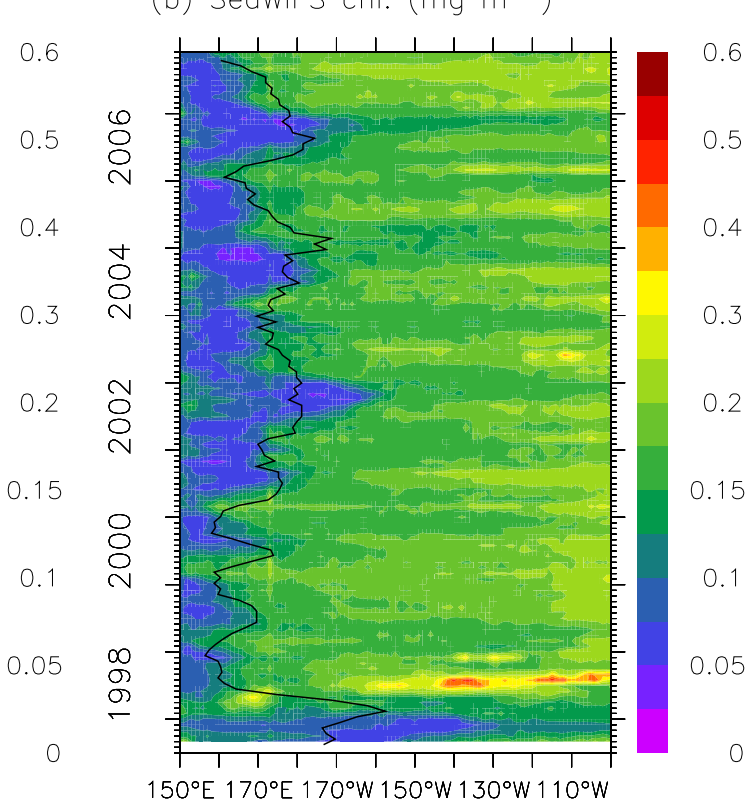

(c)

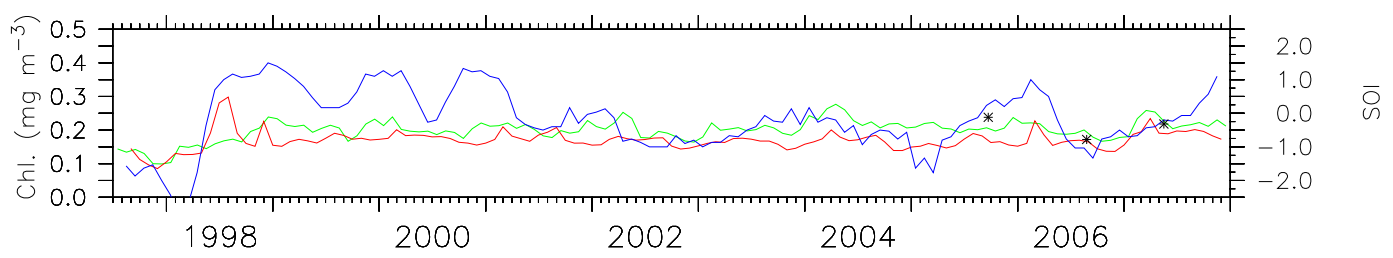

Fig. 6. Averaged surface chlorophyll concentration for time-longitude contours from (a) model and (b) SeaWiFS over $5^{\circ} \mathrm{N}-5^{\circ} \mathrm{S}$, and (c) time series for the box of $8^{\circ} \mathrm{N}-8^{\circ} \mathrm{S}, 140^{\circ} \mathrm{W}-125^{\circ} \mathrm{W}$ from the model (green line), SeaWiFS (red line) and in situ measurement (symbol). The black lines in (a) and (b) denote the HNLC front, and blue line in (c) the Southern Oscillation Index (SOI). 


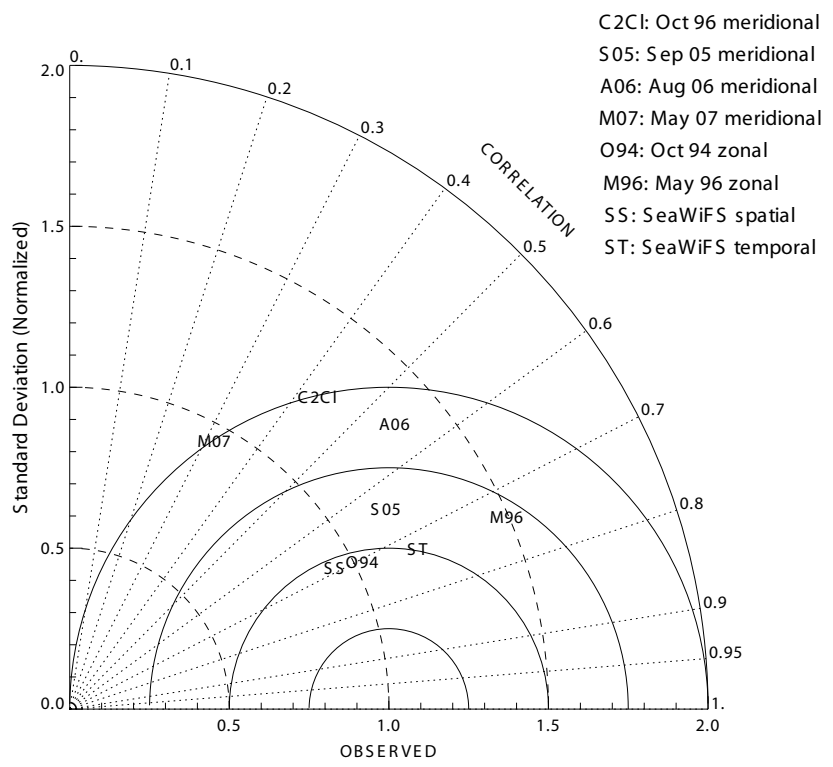

Fig. 7. Taylor diagram for model skill assessments. Data sets include zonal-vertical distributions of Chl during October 1994 (O94) and May 1996 (M96), and meridional-vertical distributions of C:Chl ratio $(\mathrm{C} 2 \mathrm{Cl})$ along $180^{\circ}$ during October-November 1996 , and $\mathrm{Chl}$ along $125^{\circ} \mathrm{W}$ and $140^{\circ} \mathrm{W}$ during September 2005 (S05), during August 2006 (A06) and during May 2007 (M07). Ten years (1998-2007) of surface chlorophyll derived from SeaWiFS are used for spatial (SS) and temporal (ST) comparisons.

gion, have been characterized in the Equatorial Pacific (Le Borgne et al., 2002b). Apparently, eliminating both nitrate and iron effects produces the largest changes in the phytoplankton C:Chl ratio in the Equatorial Pacific (Figs. 9d and $10 \mathrm{~g})$.

Statistical analyses are applied to the model outputs to quantify the effects of the variability in the SST, iron and nitrate on the phytoplankton $\mathrm{C}: \mathrm{Chl}$ ratio. Three regions are examined: the warm pool $\left(160^{\circ}-180^{\circ} \mathrm{E}, 5^{\circ} \mathrm{N}-5^{\circ} \mathrm{S}\right)$, the frontal region $\left(180^{\circ}-160^{\circ} \mathrm{W}, 5^{\circ} \mathrm{N}-5^{\circ} \mathrm{S}\right)$, and the central Equatorial Pacific $\left(160^{\circ}-140^{\circ} \mathrm{W}, 5^{\circ} \mathrm{N}-5^{\circ} \mathrm{S}\right)$. Three criteria are used to assess the sensitivity of the $\mathrm{C}$ :Chl ratio (referring as $X$ ). The first one is the bias which is the difference of the averages $(\bar{X})$ between an experiment $(s)$ and the standard simulation $(c)$. The second is the correlation $(r)$ between the two simulations. The last is the NSD:

$\mathrm{NSD}=\sqrt{\frac{\frac{1}{n} \sum_{1}^{n}(X s-\bar{X} s)^{2}}{\frac{1}{n} \sum_{1}^{n}(X c-\bar{X} c)^{2}}}$,

where $n$ is the number of the values for each experiment. A best match between an experiment and the standard simulation, i.e. indications of closest to zero for the bias, and closest to one for both the $r$ and the NSD, suggests that the
Table 4. Statistics of $\mathrm{C}$ : Chl ratio in the surface $(20 \mathrm{~m})$ and subsurface $(60 \mathrm{~m})$ in different regions.

\begin{tabular}{|c|c|c|c|c|c|c|c|c|}
\hline \multirow[b]{2}{*}{ Experiment } & \multicolumn{4}{|c|}{$20 \mathrm{~m}$} & \multicolumn{4}{|c|}{$60 \mathrm{~m}$} \\
\hline & Value & Bias & $\begin{array}{l}\text { Corre- } \\
\text { lation }\end{array}$ & NSD & Value & Bias & $\begin{array}{l}\text { Corre- } \\
\text { lation }\end{array}$ & NSD \\
\hline \multicolumn{9}{|c|}{$160^{\circ}-180^{\circ} \mathrm{E}, 5^{\circ} \mathrm{N}-5^{\circ} \mathrm{S}$} \\
\hline (1) Standard & 186 & & & & 134 & & & \\
\hline (2) SSTM & 188 & 2 & 0.998 & 0.84 & 135 & 1 & 0.996 & 0.88 \\
\hline (3) $\mathrm{FeM}$ & 179 & -7 & 0.985 & 1.76 & 129 & -5 & 0.968 & 1.57 \\
\hline (4) $\mathrm{NO}_{3} \mathrm{M}$ & 113 & -73 & 0.683 & 1.26 & 82 & -52 & 0.676 & 1.00 \\
\hline (5) $\mathrm{FeNO}_{3} \mathrm{M}$ & 94 & -92 & 0.387 & 0.10 & 70 & -64 & 0.438 & 0.28 \\
\hline \multicolumn{9}{|c|}{$180^{\circ}-160^{\circ} \mathrm{W}, 5^{\circ} \mathrm{N}-^{\circ} \mathrm{S}$} \\
\hline (1) Standard & 141 & & & & 100 & & & \\
\hline (2) SSTM & 147 & 6 & 0.991 & 1.03 & 104 & 4 & 0.994 & 1.02 \\
\hline (3) FeM & 105 & -35 & 0.856 & 1.22 & 76 & -23 & 0.894 & 1.22 \\
\hline (4) $\mathrm{NO}_{3} \mathrm{M}$ & 130 & -11 & 0.731 & 0.71 & 91 & -9 & 0.726 & 0.64 \\
\hline (5) $\mathrm{FeNO}_{3} \mathrm{M}$ & 94 & -47 & 0.680 & 0.10 & 67 & -32 & 0.438 & 0.28 \\
\hline \multicolumn{9}{|c|}{$160^{\circ}-140^{\circ} \mathrm{W}, 5^{\circ} \mathrm{N}-5^{\circ} \mathrm{S}$} \\
\hline (1) Standard & 97 & & & & 67 & & & \\
\hline (2) SSTM & 97 & 0 & 0.993 & 1.08 & 67 & 0 & 0.994 & 1.06 \\
\hline (3) FeM & 92 & -5 & 0.606 & 0.26 & 63 & -4 & 0.709 & 0.45 \\
\hline (4) $\mathrm{NO}_{3} \mathrm{M}$ & 96 & -1 & 0.994 & 0.93 & 67 & 0 & 0.994 & 0.96 \\
\hline (5) $\mathrm{FeNO}_{3} \mathrm{M}$ & 92 & -5 & 0.650 & 0.26 & 63 & -4 & 0.705 & 0.45 \\
\hline
\end{tabular}

tested variable has the smallest influence out of all the variables on the phytoplankton $\mathrm{C}$ : Chl ratio. Conversely, bigger the mismatch, larger the effect the tested variable has.

Table 4 and Fig. 11 present the averaged C:Chl ratio and statistics for the three regions. Apparently, the SSTM experiment reveals the best match in the warm pool and the frontal region, and the $\mathrm{NO}_{3} \mathrm{M}$ in the $\mathrm{HNLC}$ region. In addition, the SSTM produce zero bias, high correlation $(r=0.993-0.994)$ and almost perfect NSD (1.06-1.08) in the HNLC region. These analyses indicate that temperature has little effect on the phytoplankton C:Chl ratio in the entire Equatorial Pacific, and nitrate in the HNLC region. For the warm pool, the FeM simulates much smaller bias and higher correlation $(r>0.96)$ than the $\mathrm{NO}_{3} \mathrm{M}$, suggesting that nitrate plays a larger role in determining the phytoplankton $\mathrm{C}: \mathrm{Chl}$ ratio than iron. However, the NSD is close to one in the $\mathrm{NO}_{3} \mathrm{M}$, which indicates that nitrate has little effect on the spatial variability though it regulates the magnitude of the $\mathrm{C}: \mathrm{Chl}$ ratio in the warm pool. Interestingly, removing both nitrate and iron effects (i.e., the $\mathrm{FeNO}_{3} \mathrm{M}$ ) produces much larger bias, lower correlation and smaller NSD than only eliminating nitrate (i.e., the $\mathrm{NO}_{3} \mathrm{M}$ ), reflecting complex interaction of nitrate and iron limitations west of the dateline (Behrenfeld et al., 2006).

Figure 11 shows that both the correlation and NSD are slightly closer to one in the $\mathrm{FeM}$ than in the $\mathrm{NO}_{3} \mathrm{M}$ in the frontal region, suggesting that nitrate may play a bigger role in regulation of the spatial variability of $\mathrm{C}: \mathrm{Chl}$ ratio. However, the bias is larger in the $\mathrm{FeM}(>20 \%)$ than in the $\mathrm{NO}_{3} \mathrm{M}$ $(<10 \%)$ (Table 4), indicating relatively larger effect of iron on the phytoplankton $\mathrm{C}: \mathrm{Chl}$ ratio than nitrate in this region. These analyses demonstrate that the Taylor diagrams of correlation and NSD provide a good assessment of model 
(a) Variable C:Chl ratio

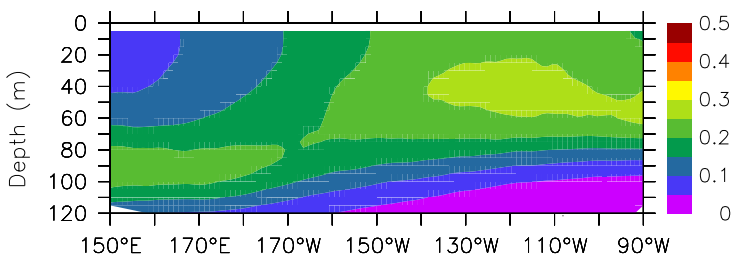

(c) Constant C:Chl ratio

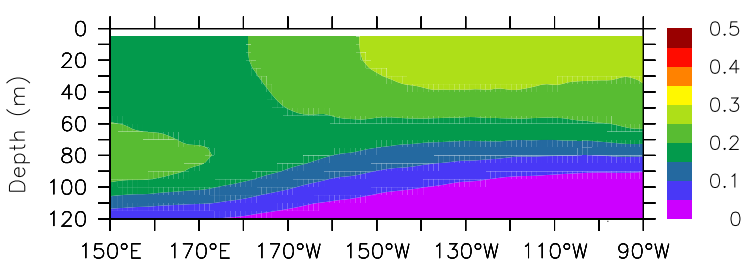

(e) C:Chl ratio decreasing over depth

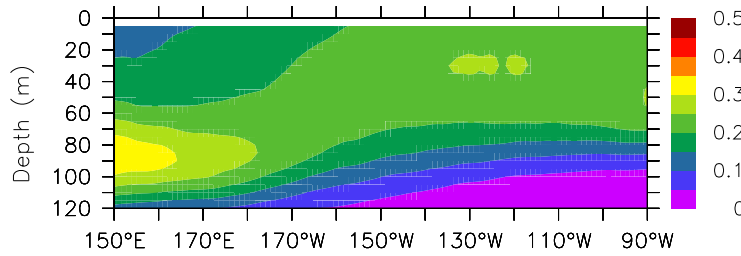

(b) Variable c:Chl ratio

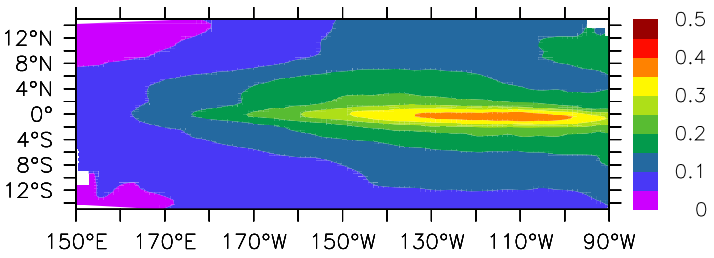

(d) Constant $\mathrm{C}:$ Chl ratio

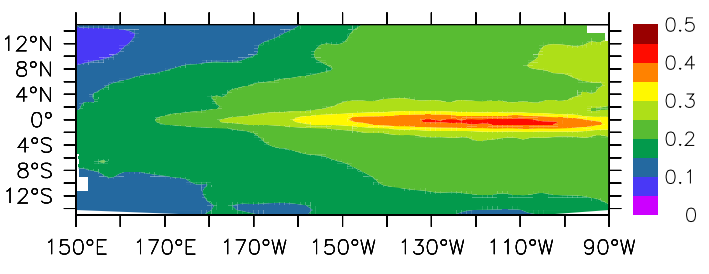

(f) C:Chl ratio decreasing over depth

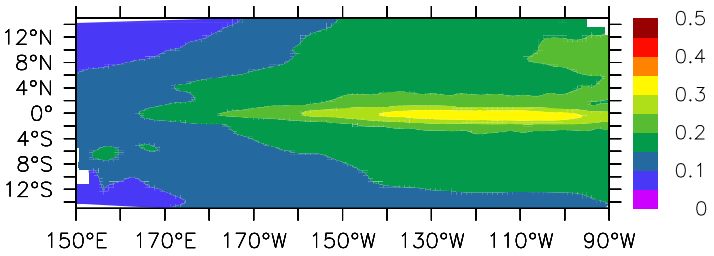

Fig. 8. Chl concentrations from (a) and (b) standard simulation with a variable C:Chl ratio, and generated from phytoplankton carbon biomass using (c) and (d) a constant C:Chl ratio of $80 \mathrm{~g}: \mathrm{g}$, and (e) and (f) a decreasing C:Chl ratio over depth from $100 \mathrm{~g}: \mathrm{g}$ at the surface to $50 \mathrm{~g}: \mathrm{g}$ at $100 \mathrm{~m}$.

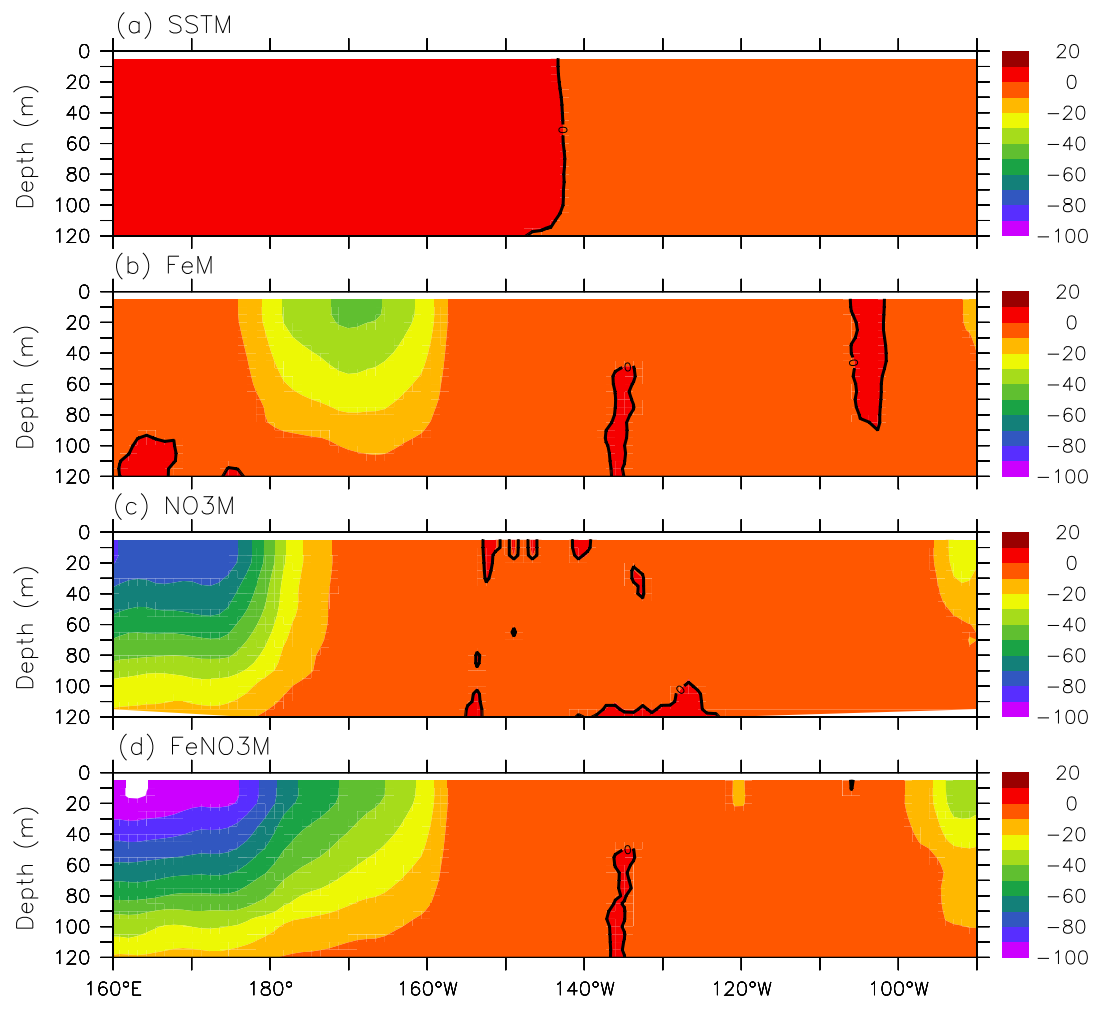

Fig. 9. Difference in the phytoplankton C:Chl ratio between the standard simulation and (a) SSTM, (b) FeM, (c) $\mathrm{NO}_{3} \mathrm{M}$, and (d) $\mathrm{FeNO} \mathrm{N}_{3} \mathrm{M}$ over $5^{\circ} \mathrm{N}-5^{\circ} \mathrm{S}$, depth versus longitude. 

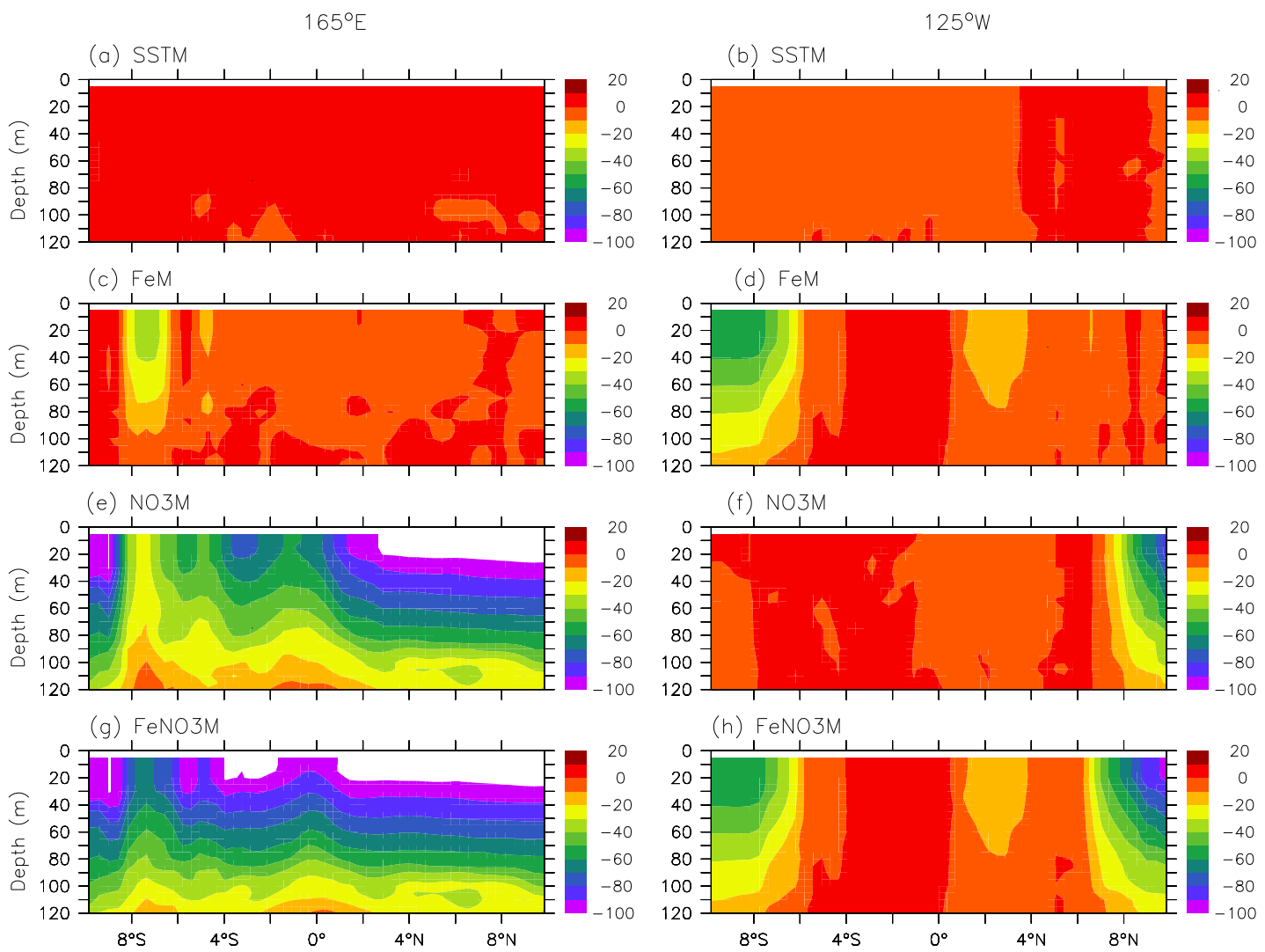

Fig. 10. Difference in the phytoplankton C:Chl ratio between the standard simulation and (a) and (b) SSTM, (c) and (d) FeM, (e) and (f) $\mathrm{NO}_{3} \mathrm{M}$, and (g) and (h) $\mathrm{FeNO}_{3} \mathrm{M}$ along $165^{\circ} \mathrm{E}$ (left panel) and $125^{\circ} \mathrm{W}$ (right panel).

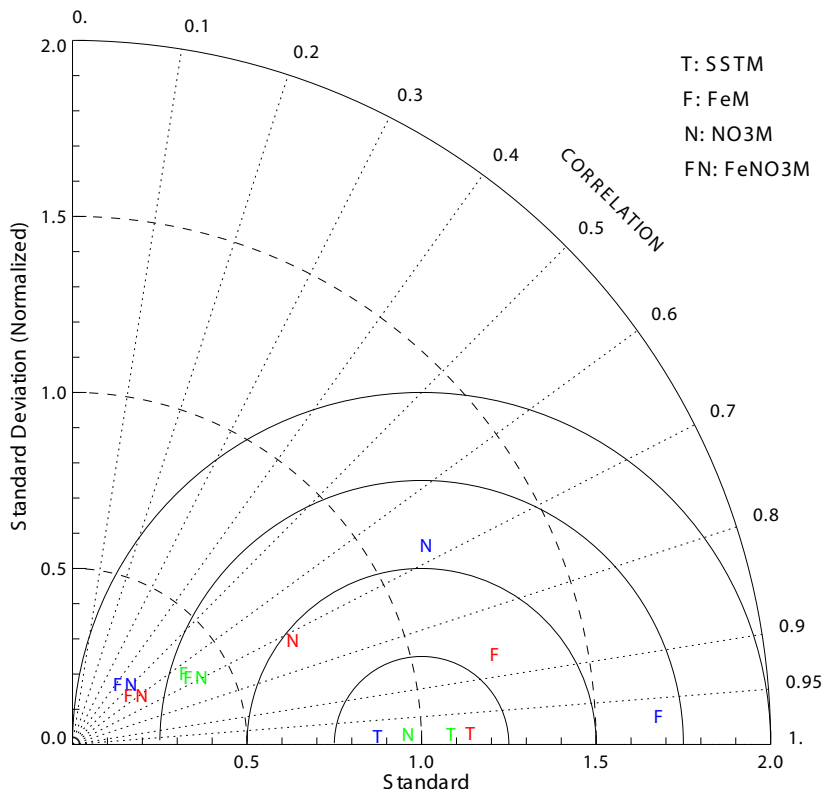

Fig. 11. Taylor diagram for model sensitivity studies. Diagrams are shown for the boxes of $160^{\circ}-180^{\circ} \mathrm{E} 5^{\circ} \mathrm{N}-5^{\circ} \mathrm{S}$ (blue color), $180^{\circ}-$ $160^{\circ} \mathrm{W}, 5^{\circ} \mathrm{N}-5^{\circ} \mathrm{S}$ (red color) and $160^{\circ}-140^{\circ} \mathrm{W}, 5^{\circ} \mathrm{N}-5^{\circ} \mathrm{S}$ (green color). skill in terms of reproducing variability, but model bias indicates a model's ability to reproduce observed mean conditions.

\section{Summary and conclusions}

We have carried out a basin-scale modeling study of phytoplankton dynamics, and explored the regulation of light, iron, nitrate and temperature with a non-steady $\mathrm{C}: \mathrm{Chl}$ ratio in the Equatorial Pacific. While there are limited data of the phytoplankton $\mathrm{C}: \mathrm{Chl}$ ratio in this region, there is a considerable amount of in situ Chl data for the upper water column with reasonably good spatial and temporal coverage in addition to the surface $\mathrm{Chl}$ derived from the SeaWiFS imagery. Our model faithfully reproduces the general features of phytoplankton dynamics in this region, including not only the zonal, meridional and vertical variations, but also the interannual variability of $\mathrm{Chl}$ concentrations. The large spatiotemporal contrasts in physical and biogeochemical fields in the Equatorial Pacific make this region an ideal test bed for exploring the regulation of light, nutrients and temperature on the phytoplankton $\mathrm{C}: \mathrm{Chl}$ ratio. We have demonstrated the applicability of the new $\mathrm{C}: \mathrm{Chl}$ dynamic model by revealing that nitrate and iron together regulate the zonal and meridional variations in the $\mathrm{C}: \mathrm{Chl}$ ratio, thus, $\mathrm{Chl}$ dynam- 
ics in the Equatorial Pacific. Nitrate is responsible for the high $\mathrm{C}$ :Chl ratio in the western warm pool while iron determines the displacement of the HNLC front. Light is primarily responsible for the vertical decrease of phytoplankton $\mathrm{C}: \mathrm{Chl}$ ratio. Temperature has a relatively small effect on the $\mathrm{C}$ :Chl ratio in the Equatorial Pacific.

Acknowledgements. This research is supported by National Aeronautics and Space Administration (NASA). We thank NASA for providing SeaWiFS derived Chl data. We thank Julie Arrington for the in situ POC and Chl measurements. We appreciate the constructive comments of two anonymous reviewers, Christoph Voelker and Anand Gnanadesikan.

Edited by: F. Joos

\section{References}

Armstrong, R. A.: Optimality-based modeling of nitrogen allocation and photoacclimation in photosynthesis, Deep-Sea Res. Pt. II, 53, 513-531, 2006.

Aumont, O., Maier-Reimer, E., Blain, S., and Monfray, P.: An ecosystem model of the global ocean including $\mathrm{Fe}$, Si, P colimitations, Global Biogeochem. Cy., 17, 1060, doi:10.1029/2001GB001745, 2003.

Behrenfeld, M. J. and Falkowski, P. G.: Photosynthetic rates derived from satellite-based chlorophyll concentration, Limnol. Oceanogr., 42, 1-20, 1997.

Behrenfeld, M. J., Maranon, E., Siegel, D. A., and Hooker, S. B.: Photoacclimation and nutrientbased model of light-saturated photosynthesis for quantifying oceanic primary production, Mar. Ecol.-Prog. Ser., 228, 103-117, 2002.

Behrenfeld, M. J., Boss, E., Siegel, D. A., and Shea, D. M.: Carbon-based ocean productivity and phytoplankton physiology from space, Global Biogeochem. Cy., 19, GB1006, doi:10.1029/2004GB002299, 2005.

Behrenfeld, M. J. and Boss, E.: Beam attenuation and chlorophyll concentration as alternative optical indices of phytoplankton biomass, J. Mar. Res., 64, 431-451, 2006.

Behrenfeld, M. J., Worthington, K., Sherrell, R. M., Chavez, F. P., Strutton, P., McPhaden, M., and Shea, D. M.: Controls on tropical Pacific Ocean productivity revealed through nutrient stress diagnostics, Nature, 442, 1025-1028, 2006.

Blanchot, J., Andre, J. M., Navarette, C., Neveux, J., and Radenac, M. H.: Picophytoplankton in the equatorial Pacific: vertical distributions in the warm pool and in the high nutrient low chlorophyll conditions, Deep-Sea Res. Pt. I, 48, 297-314, 2001.

Brown, S. L., Landry, M. R., Neveux, J., and Dupouy, C.: Microbial community abundance and biomass along a 180 degrees transect in the equatorial Pacific during an El NinoSouthern Oscillation cold phase, J. Geophys. Res., 108, 8139, doi:10.1029/2001JC000817, 2003.

Carr, M.-E., Friedrichs, M. A. M., Schmeltz, M., Noguchi Aita, M., Antoine, D., Arrigo, K. R., Asanuma, I., Aumont, O., Barber, R., and Behrenfeld, M.: A comparison of global estimates of marine primary production from ocean color, Deep-Sea Res. Pt. II, 53, 741-770, 2006.

Chavez, F. P., Buck, K. R., Service, S. K., Newton, J., and Barber, R. T.: Phytoplankton variability in the central and eastern tropical Pacific, Deep-Sea Res. Pt. II, 43, 835-870, 1996.

Chen, D., Rothstein, L. M., and Busalacchi, A. J.: A hybrid vertical mixing scheme and its application to tropical ocean models, J. Phys. Oceanogr., 24, 2156-2179, 1994.

Christian, J. R., Verschell, M. A., Murtugudde, R., Busalacchi, A. J., and McClain, C. R.: Biogeochemical modelling of the tropical Pacific Ocean. I: Seasonal and interannual variability, Deep-Sea Res. Pt. II, 49, 509-543, 2002.

Cloern, J. E., Grenz, C., and VidergarLucas, L.: An empirical model of the phytoplankton chlorophyll:carbon ratio - The conversion factor between productivity and growth rate, Limnol. Oceanogr., 40, 1313-1321, 1995.

Coale, K. H., Fitzwater, S. E., Gordon, R. M., Johnson, K. S., and Barber, R. T.: Control of community growth and export production by upwelled iron in the equatorial Pacific Ocean, Nature, 379, 621-624, 1996.

Doney, S. C., Lima, I., Moore, J. K., Lindsay, K., Behrenfeld, M. J., Westberry, T. K., Mahowald, N., Glover, D. M., and Takahashi, T.: Skill metrics for confronting global upper ocean ecosystembiogeochemistry models against field and remote sensing data, Journal of Marine Systems, 76, 95-112, 2009.

Eldin, G. and Rodier, M.: Ocean physics and nutrient fields along 180 degrees during an El Nino-Southern Oscillation cold phase, J. Geophys. Res., 108, 8137, doi:10.1029/2000JC000746, 2003.

Faugeras, B., Bernard, O., Sciandra, A., and Levy, M.: A mechanistic modelling and data assimilation approach to estimate the carbon/chlorophyll and carbon/nitrogen ratios in a coupled hydrodynamical-biological model, Nonlin. Processes Geophys., 11, 515-533, 2004, http://www.nonlin-processes-geophys.net/11/515/2004/.

Faure, V., Pinazo, C., Torreton, J. P., and Douillet, P.: Relevance of various formulations of phytoplankton chlorophyll a : carbon ratio in a 3D marine ecosystem model, C. R. Biol., 329, 813-822, 2006.

Fennel, K. and Boss, E.: Subsurface maxima of phytoplankton and chlorophyll: Steady-state solutions from a simple model, Limnol. Oceanogr., 48, 1521-1534, 2003.

Fujii, M., Boss, E., and Chai, F.: The value of adding optics to ecosystem models: a case study, Biogeosciences, 4, 817-835, 2007, http://www.biogeosciences.net/4/817/2007/.

Geider, R. J., Macintyre, H. L., and Kana, T. M.: A dynamic model of photoadaptation in phytoplankton, Limnol. Oceanogr., 41, 1$15,1996$.

Geider, R. J., MacIntyre, H. L., and Kana, T. M.: Dynamic model of phytoplankton growth and acclimation: responses of the balanced growth rate and the chlorophyll a:carbon ratio to light, nutrient-limitation and temperature, Mar. Ecol.-Prog. Ser., 148, 187-200, 1997.

Geider, R. J., Macintyre, H. L., and Kana, T. M.: A dynamic regulatory model of phytoplanktonic acclimation to light, nutrients, and temperature, Limnol. Oceanogr., 43, 679-694, 1998.

Gent, P. R. and Cane, M. A.: A reduced gravity, primitive equation model of the upper Equatorial Ocean, J. Comput. Phys., 81, 444480, 1989. 
Hackert, E. C., Busalacchi, A. J., and Murtugudde, R.: A wind comparison study using an ocean general circulation model for the 19991998 El Nino, J. Geophys. Res., 106, 2345-2362, 2001.

Ishizaka, J., Harada, K., Ishikawa, K., Kiyosawa, H., Furusawa, H., Watanabe, Y., Ishida, H., Suzuki, K., Handa, N., and Takahashi, M.: Size and taxonomic plankton community structure and carbon flow at the equator, $175^{\circ}$ E during 1990-1994, Deep-Sea Res. Pt. II, 44, 1927-1949, 1997.

Kalnay, E., Kanamitsu, M., Kistler, R., Collins, W., Deaven, D., Gandin, L., Iredell, M., Saha, S., 15 White, G., Woollen, J., Zhu, Y., Chelliah, M., Ebisuzaki, W., Higgins, W., Janowiak, J., Mo, K. C., Ropelewski, C., Wang, J., Leetmaa, A., Reynolds, R., Jenne, R., and Joseph, D.: The NCEP/NCAR 40-year reanalysis project, B. Am. Meteorol. Soc., 77, 437-471, 1996.

Le Borgne, R., Barber, R. T., Delcroix, T., Inoue, H. Y., Mackey, D. J., and Rodier, M.: Pacific warm pool and divergence: temporal and zonal variations on the equator and their effects on the biological pump, Deep-Sea Res. Pt. II, 49, 2471-2512, 2002a.

Le Borgne, R., Feely, R. A., and Mackey, D. J.: Carbon fluxes in the equatorial Pacific: a synthesis of the JGOFS programme, DeepSea Res. Pt. II, 49, 2425-2442, 2002 b.

Le Borgne, R. and Landry, M. R.: EBENE: A JGOFS investigation of plankton variability and trophic interactions in the equatorial Pacific (180 degrees), J. Geophys. Res., 108, 8136, doi:10.1029/2001JC001252, 2003.

Le Bouteiller, A., Leynaert, A., Landry, M. R., Le Borgne, R., Neveux, J., Rodier, M., Blanchot, J., and Brown, S. L.: Primary production, new production, and growth rate in the equatorial $\mathrm{Pa}$ cific: Changes from mesotrophic to oligotrophic regime, J. Geophys. Res., 108, 8141, doi:10.1029/2001JC000914, 2003.

Lefevre, N., Taylor, A. H., Gilbert, F. J., and Geider, R. J.: Modeling carbon to nitrogen and carbon to chlorophyll a ratios in the ocean at low latitudes: Evaluation of the role of physiological plasticity, Limnol. Oceanogr., 48, 1796-1807, 2003.

Mackey, D. J., Blanchot, J., Higgins, H. W., and Neveux, J.: Phytoplankton abundances and 5 community structure in the equatorial Pacific, Deep-Sea Res. Pt. II, 49, 2561-2582, 2002.

Martin, J. H., Coale, K. H., Johnson, K. S., Fitzwater, S. E., Gordon, R. M., Tanner, S. J., Hunter, C. N., Elrod, V. A., Barber, R. T., Lindley, S., Watson, A. J., and Van Scoy, K.: Testing the iron hypothesis in ecosystems of the equatorial Pacific Ocean, Nature, 371, 123-129, 1994.

McClain, C. R., Christian, J. R., Signorini, S. R., Lewis, M. R., Asanuma, I., Turk, D., and Dupouy-Douchement, C.: Satellite ocean-color observations of the tropical Pacific Ocean, Deep-Sea Res. Pt. II, 49, 2533-2560, 2002.

Moore, J. K., Doney, S. C., Kleypas, J. A., Glover, D. M., and Fung, I. Y.: An intermediate 10 complexity marine ecosystem model for the global domain, Deep-Sea Res. Pt. II, 49, 403-462, 2002.

Murtugudde, R., Seager, R., and Busalacchi, A.: Simulation of the tropical oceans with an ocean GCM coupled to an atmospheric mixed-layer model, J. Climate, 9, 1795-1815, 1996.

Murtugudde, R., Beauchamp, J., McClain, C. R., Lewis, M., and Busalacchi, A. J.: Effects of penetrative radiation on the upper tropical ocean circulation, J. Climate, 15, 470-486, 2002.

Neveux, J., Dupouy, C., Blanchot, J., Le Bouteiller, A., Landry, M. R., and Brown, S. L.: Diel dynamics of chlorophylls in high-nutrient, low-chlorophyll waters of the equatorial Pacific (180 degrees): Interactions of growth, grazing, physiological responses, and mixing, J. Geophys. Res.-Oceans, 108, 8140, doi:10.1029/2000JC000747, 2003.

Pahlow, M.: Linking chlorophyll-nutrient dynamics to the Redfield $\mathrm{N}$ : C ratio with a model of optimal phytoplankton growth, Marine Ecology-Progress Series, 287, 33-43, 2005.

Picaut, J., Ioualalen, M., Delcroix, T., Masia, F., Murtugudde, R., and Vialard, J.: The oceanic zone of convergence on the eastern edge of the Pacific warm pool: A synthesis of results and implications for El Nino-Southern Oscillation and biogeochemical phenomena, J. Geophys. Res., 106, 2363-2386, 2001.

Raimbault, P., Slawyk, G., Boudjellal, B., Coatanoan, C., Conan, P., Coste, B., Garcia, N., Moutin, T., and Pujo-Pay, M.: Carbon and nitrogen uptake and export in the Equatorial Pacific at 150 degrees W: Evidence of an efficient regenerated production cycle, J. Geophys. Res., 104, 3341-3356, 1999.

Smith, S. L. and Yamanaka, Y.: Optimization-based model of multinutrient uptake kinetics, Limnol. Oceanogr., 52, 1545-1558, 2007.

Taylor, A. H., Geider, R. J., and Gilbert, F. J. H.: Seasonal and latitudinal dependencies of 25 phytoplankton carbon-to-chlorophyll a ratios: Results of a modelling study, Mar. Ecol.-Prog. Ser., 152, 51-66, 1997.

Taylor, K. E.: Summarizing multiple aspects of model performance in a single diagram, J. Geophys. Res., 106, 7183-7192, 2001.

Wang, X. J., Christian, J., Murtugudde, R., and Busalacchi, A.: Ecosystem dynamics and export production in the central and eastern equatorial Pacific: a modeling study of impact of ENSO, Geophys. Res. Lett., 32, L02608, doi:10.1029/2004GL021538, 2005.

Wang, X. J., Christian, J. R., Murtugudde, R., and Busalacchi, A. J.: Spatial and temporal variability of the surface water $\mathrm{pCO}_{2}$ and air-sea $\mathrm{pCO}_{2}$ flux in the equatorial Pacific during 19802003: a basin-scale carbon model, J. Geophys. Res., 111, C07S04, doi:10.1029/2005JC002972, 2006a.

Wang, X. J., Christian, J. R., Murtugudde, R., and Busalacchi, A. J.: Spatial and temporal variability in new production in the equatorial Pacific during 1980-2003: Physical and biogeochemical controls, Deep-Sea Res. Pt. II, 53, 677-697, 2006 b.

Wang, X. J., Le Borgne, R., Murtugudde, R., Busalacchi, A. J., and Behrenfeld, M.: Spatial and temporal variations in dissolved and particulate organic nitrogen in the Equatorial Pacific: biological and physical influences, Biogeosciences, 5, 1705-1721, 2008, http://www.biogeosciences.net/5/1705/2008/.

Wang, X. J., Le Borgne, R., Murtugudde, R., Busalacchi, A., and Behrenfeld, M. J.: Spatial and temporal variability of the phytoplankton carbon to chlorophyll ratio in the Equatorial Pacific: a basin scale model study., J. Geophys. Res., revised, 2009.

Westberry, T., Behrenfeld, M. J., Siegel, D. A., and Boss, E.: Carbon-based primary productivity modeling with vertically resolved photoacclimation, Global Biogeochem. Cy., 22, GB2024, 10 doi:10.1029/2007gb003078, 2008.

Wetzel, P., Maier-Reimer, E., Botzet, M., Jungclaus, J., Keenlyside, N., and Latif, M.: Effects of ocean biology on the penetrative radiation in a coupled climate model, J. Climate, 19, 3973-3987, 2006. 